\title{
A COMPARATIVE STUDY: GENETIC STRUCTURALISM ON JANE EYRE AND THE GREAT GATSBY
}

\author{
Dewi Christa Kobis. STMIK Multicom Bolaang Mongondow \\ dechriskobis@gmail..com
}

\begin{abstract}
Abstrak
Penelitian ini merupakan penelitian komparatif yang membandingkan novel Jane Eyre dan the Great Gatsby dengan menggunakan teori Strukturalisme Genetik. Kedua novel ini ditulis dan terbit dari era yang berbeda. Masa yang berbeda pada umumnya menghasilkan budaya, tradisi, kebiasaan, karya, ciptaan, usaha, dan bahkan karya agung yang berbeda satu sama lain. Seiring berjalannya waktu, yang tuah akan digantikan dengan yang mudah, dan segala hal yang terjadi di masa lampau, tak akan terjadi dimasa sekarang atau bahkan dimasa depan. Nyatanya, adalah perlu untuk menggali lebih dalam lagi tentang sejarah itu sendiri untuk mengetahui bagaimana masarakat di suatu era tertentu hidup dan bagaimana mereka membentuk sebuah komunitas. Peneltian ini dirangkai sebagai penelitian yang mempelajari karakteristik dari masyarakat ketika karya-karya sastra tersebut diterbitkan dan era dimana para penulisnya hidup dan juga berfokus secara terpusat tentang bagaimana masyarakat mempengaruhi pemikiran dan persepsi dari para penulis untuk menciptakan karya sastra tersebut.
\end{abstract}

Kata Kunci: Jane Eyre, the Great Gatsby, Strukturalisme Genetik, Karakteristik, Era.

\section{INTRODUCTION}

The time period might tell story and history about many things in human's life include in human's literary work. An author who is being a part of a society might produce a story related to his knowledge of the society where and when he or she lives. The experience and values of the author as part of his society influence his works, and this can appear through the character he creates. Even though the character he creates is just imaginary character, it is acting and talking like a real person (Nur'aini, 2009). Since the author might produce a literary work based on the society where and when she or he lives, it is important to consider about the characteristic of the society based on its period. After considering about the time period, the researcher started to be curious about how different periods create different kind of story especially in literature.

\section{Background of the Study}

Different time periods might produce different history. That history might be revealed through written document. Meyer (1997) also clarifies that different historical periods are reflected in literature. That is why the period of when the literature is produced is necessary to be researched. The time is inanimate object. But what happened in the society during a time period might produce several useful facts related to the literature. Regarding to this fact, the researcher chose two different novels from two different periods to be compared. The first one is from the mid-nineteenth century entitled "Jane Eyre" which had been published in 1847 and the second one is from the nineteenth century entitled "the Great Gatsby" which had been published in 1928.

There are several reasons why the researcher chose these two novels. The first is the mid-nineteenth century is the time when the 
novelists from the low social status especially female writers struggled to find equality in literature since at that time only male writers who got privilege to publish their literary works (Martin, 1996). The time period where the novelists were still struggling to publish their works is worthy to be analyzed since it was the period when female writers were oppressed. The second reason is the nineteenth century is a period when people from any social status were able to get the literary works easily because printed machines were produced in large numbers and literary works are not things that could be enjoyed by the people who were from the high society only since the price of the novels or other literary works were affordable (Schneider, 2007).The time period when every people from any society were able to buy any kind of literary works is feasible to be researched so that we are able to know the opinions from those who are from high and low social status regarding the novel.

The third reason is Jane Eyre is a novel which was mostly written based on the author's real life. Sumo (2005) mentions that regardless of her intentions while writing Jane Eyre, it is clear that Charlotte Bronte drew heavily on her own identity and experiences in creating the character of Jane" (Sumo, 2005,para. 1).A novel which had been a reflection of an author's real life might reflect the society at the period when the novel is published. Thus, Jane Eyre might be a good example to be used in this study. The last reason is in the Great Gatsby, Fitzgerald (the author) "effectively offers a powerful critique of a materialistic society and the effects it can have on one's hopes and dreams" (Bloom, 1985, p.21). A novel that had been written as the critique in the society is worthy to be used in a research since it will represent the condition of the society at the period. Based on these reasons, the researcher concludes that the novel Jane Eyre that represents mid-nineteenth century and the Great Gatsby that represents nineteenth century are suitable to be used in this research.

This study uses genetic structuralism as its approach. Genetic structuralism is a term applied by Goldmann to his historicist Marxist methodology. Methodologically, Goldmann (1971) sees all human behavior as a significant structure that may be understood. $\mathrm{He}$ differentiates perception or interpretation, which is a representation of fundamental universal and indefinite construction, from explanation, that is begun by the process of identifying laws and causes. He believes that literary work "is not only an imaginative fact and personal imagination, but also as a reflection of culture record, a shape of certain mind when literary work was created" (Goldman, 1971, p.156). Therefore, a literary work is not just produced by an imagination but also by the influence of a culture in a society. By considering this information, the researcher decided to do comparative study on Jane Eyre and the Great Gatsby using genetic structuralism to know how the culture in the society of when these two novels were written impacted the production of the novels.

\section{RESEARCH METHOD}

The method of this research is qualitative descriptive and the technique of collecting data is library research. This research is a comparative study that compares Jane Eyre and the Great Gatsby using genetic structuralism analysis by Lucien Goldmann. Bassnett (1993) proposes that comparative literature engages a 
study "of texts across cultures, that it is interdisciplinary and that it is concerned with patterns of connection in literatures across both time and space" (p.1). Since comparative study aims to find the similarities and differences between texts or authors from different cultural context, that is why the comparison between Jane Eyre as British literature from midnineteenth century and the Great Gatsby as American literature from nineteenth century fulfill the aim of comparative study, so this study could be called a comparative study.

\subsection{Genetic Structuralism in Literary Works}

Genetic structuralism is divided into two words for its definition based on its founder's perception, Lucien Goldman. The first is "structuralism." Structuralism, because he was not interesting much in meticulous world vision's contents than in the structure of groups it shows. The second is "genetic." Genetic, "because Goldman is worried of how such mental structures are historically producedconcern, that is to say, with the relation between a world vision and the historical conditions which give rise to it" (Eagleton, 1976, p.15). So, genetic structuralism is like a particular world vision which was derived from the produced mental structure that has been completed through historical process. Terry Eagleton (1976) notes that social relations between men are bound up with the way they produce their material life. In other words, what had been produced by men is the production of men's relations in the society.

This passage illuminates us that we need to comprehend the social process to understand the literature. Since social relations related to social mentality, the production of literature is produced by formed perception that has relation with the ideology of an age. So, every age might have its own ideology in a social relation, and then create a social mentality then produce a literature work. It shows us that social condition really determines the production of literary work across the time period. For addition, Nur'aini (2009) on her thesis entitled Genetic Structuralism Analysis on Lucky Jim by Kingsley Amis found that "the correlation between literary work and historical background is reflected in Kingsley Amis' novel “Lucky Jim.” It is a story when British society was being restructured after World War II. Kingsley Amis as the author of the novel describes the class division in British society around 1950s. That is the government socialist ideology does not change the class distinction in British society" (p.42). This example strengthens the fact that historical background contributes an important role in literature production in a particular period.

\subsection{Jane Eyre in Literary Research}

In 2011, Angela Andersson conducted a research about Jane Eyre entitled Identity and Independence in Jane Eyre. At the beginning, she proposes about the women's condition at the mid-nineteenth century. Women at that time had no right to speak, to have proper education, to have works that they desire, and had no strength to against patriarchy. There was also social class difference at that time where people from the high social status really looked down those who are from low social status (Andersson, 2011).Thus, women at that period were so depressed and wished to be free from the pressure of patriarchy. At that time, the marriage between man from the royal family and woman from the low social status was forbidden. This was also the problem that had been risen up in 
the novel Jane Eyre. At her findings, Andersson (2011) clarifies that to free herself in the patriarchal society Jane meets and overcomes: oppression by the Reed family and $\mathrm{Mr}$. Brocklehurst, starvation at Lowood and during her wandering before reaching Marsh End, madness in the Red Room and at Thornfield and coldness by being lonely and by the way St. John treated her. Although she longs for love she does not let Rochester or St. John exploit her and in the end she finds the equal relationship she longed for. So at the end, Jane as the protagonist at Bronte's novel was success in breaking the condition that had been created by the society at that time where women from low social status were just enough for being slave or governess and not allowed to marry noble man. But Jane did the reversibility.

\subsection{The Great Gatsby in Literary Research}

There were many researches had been talked about the Great Gatsby. For instance, Louis Tyson (2006) argues that the Great Gatsby provides readers a story consists of many clarifications which explain that this novel concerns a lot about social status as its major concern more than any other issues. Based on this statement, we could conclude that the Great Gatsby is the novel which contains critiques for the society at its published time.

After considering the three researches above which are from Nur'aini that talks about Genetic Structuralism, from Andersson that talked about Jane Eyre, and from Tyson that talked about the Great Gatsby, the researcher concludes that the position of this paper is to support these three researches but the researcher will organize these three ideas through a comparative study which talked about Jane Eyre and the Great Gatsby by using genetic structuralism. So, this paper will be like the compilation of its related studies. Besides that, the researcher will add some useful information regarding the backgrounds of the novelists of Jane Eyre and the Great Gatsby to strengthen the analysis of this paper so that this paper will be comprehend well as a paper which uses genetic structuralism as its approach.

\section{DISCUSSION}

RQ 1:

What are the characteristics of the periods when were Jane Eyre and the Great Gatsby published?

\subsection{Analysis on Jane Eyre}

\section{a. Analysis on the Novelist' Background and the Novel "Jane Eyre"}

Charlotte Bronte is one of five daughters born to Reverend Patrick Bronte and Maria Branwell Bronte on April 21, 1816. Charlotte lived a sheltered life, spending most of her years confined to Haworth Church House. Charlotte's first novel that had been published is Jane Eyre. Jane Eyre's childhood in the story had similarities with Charlotte's. Like Charlotte herself, Jane's father was "a poor clergyman" (Bronte, 2011: p.26). Some parts of Jane Eyre's childhood were taken directly from Charlotte Bronte's memories. For example, the description of the Lowood School in the novel. In fact, the Lowood School in Jane Eyre was intentionally modeled after Charlotte's own experiences at Cowan Bridge School. As Lowood was obviously meant to be Cowan Bridge, despite Bronte's reluctance to have others aware of it, the similarities between the two schools merit additional analysis. However, instead of being a 
school for clergyman's daughters, as was Cowan Bridge, Lowood is "an institution for educating orphans" (Bronte, 2011, p.50). Like Cowan Bridge, each student at Lowood must pay only $£ 15$ a year, while the rest is paid for by subscription (Bronte, 2011). The condition of the family and the school that has been described in novel and the reality is quite similar.

In honor of the elder Bronte sisters, Maria and Elizabeth, who fell ill under the conditions at Cowan Bridge and died immediately following their return home, Charlotte created the character of Helen Burns. Maria is described as being "far superior in mind to any of her play-fellows and companions, and was lonely amongst them from that very cause; and yet she had faults so annoying that she was in constant disgrace with her teachers, and an object of merciless dislike to one of them, who is depicted as "Miss Scatcherd" in Jane Eyre" (Gaskell, 2004, para.1). The real-life Miss Scatcherd, a woman by the name of Miss Andrews, appears to have been the instigator of the harsh punishment Maria suffered. There is even no one of the Bronte sisters protested about their treatment, possibly because Maria convinced her younger sisters to endure their treatment and not telling anyone about that (Peters, 1974). Given that the character of Helen Burns is acknowledged to be a faithful representation of Maria Bronte.

Jane's choices of work also reflect Charlotte Bronte's own experiences with what work the Victorian world provided for women. Nestor (1987) describes the Bronte girls' up bringing as establishing "the expectation that they would need to earn their own living"(p.3). Besides marriage or keep being as a dependent of the family, the only option available for women at that period was teaching. As the consequence, Charlotte who actually disliked children worked as a teacher at Miss Wooler's school at Roe Head and at the Pensionnat Heger, as a governess twice, each time for a period of only months, and made an effort to open a school at Haworth Parsonage along with her sisters (Cody, 2004). Experiencing these trades by herself, it is not unexpected to think that Charlotte describes Jane to work as a teacher like her own experience; first as a teacher at Lowood after finishing her studies, then as a governess for Mr. Rochester, and finally as the teacher of a little school for farmers' daughters at Whitcross.

The last three years of his life, the young Mr. Reed (one of the character in Jane Eyre) spent drinking, gambling, and otherwise squandering the family estate. Whether it is coincidence or based in the reality that Charlotte knew, her biological brother named Branwell spent the last three years of his life as an alcoholic and an opium addict, and passed away one year later after Jane Eyre was published. Although Charlotte might not knowing that Branwell would die after three years of addiction, her personal experiences of watching her brother's disintegration caused her to create the fate of her character John Reed on that way.

The relationship between Jane and her employer, Mr. Rochester is similar with Charlotte's own life. During her stay in Brussels, Charlotte apparently fell in love with Monsieur Heger, who was once her teacher, and then became her employer. Charlotte's adoration for Monsieur Heger distanced her from his wife and eventually caused her unwanted in Heger's residence or at the school. When Charlotte left from Brussels, she wrote, "I think, however long I live, I shall not forget what the parting with Monsieur Heger cost me" (Gaskell, 2004. Para. 
2). Despite Rochester's appearance, however, Jane falls in love, and is soon engaged to be married to him, until she finds out that he is already married to the crazy woman he keeps locked up in the attic. Jane decides she must leave Rochester, lamenting as she runs away, "With agony I thought of what I left... I longed to be his" (Bronte, 2011, 26). Jane's sorrow when she left reflects the pain Charlotte wrote after leaving Monsieur Heger. People might perceive that the happy ending of Jane Eyre is also a reflection of Charlotte's expectation regarding Monsieur Heger. In fact, the happy ending of Jane Eyre is just Charlotte Bronte's expectation that she wished to be true.

Based on several clarifications above, we could conclude that the author's life play a crucial role in the production of her literature work. Like what happened in Jane Eyre by Charlotte Bronte, most of the characters in the novel and most of the events that have been written in the novel are reflections from the author's real life. That is why the historical structure truly determines the production of literary works.

\section{b. Analysis on the Period when "Jane Eyre" was published.}

Since Jane Eyre was published in 1847 , Jane Eyre belongs to Victorian era. Queen of England named Victoria who ruled from 1837 to 1901. Jane Eyre also reflects the condition of Victorian era. The first is the social class factor. On Victorian era, those who came from aristocrat family were so proud of their status since they were categorized as the nobles and they kept looking down to those who were from low social status. There were even the divisions for social classes which consist of upper-class, lower-class, and working class (Cody, 2002). In the novel, the character of Jane Eyre is also depicted as a lady who does not come from high social status by Bronte.

The second is the portrait of women as silent object and had lower position or status than men. Lunden et al (2009) argues that during the Victorian era, women had no rights of her own and they were expected to marry and become their husbands' servants. Lunden et al then added that there were only few professions other than governess provided for educated women of that era who needed a means to support themselves financially and professionally. Besides, being educated was considered wasted on women because they were considered mentally and physically inferior than men. Moreover, working outside the house was believed to make them ill. The education for women only consisted of learning to sing, dance, and play the piano, to draw, read, write, some arithmetic and French and to do embroidery" (Lunden et al, 2009, 147). Women still had no rights at that time. Jane Eyre, as a character that has been created by Bronte could be perceived as a distinctive woman at that period. Eyre is a character who has passion and fights for injustice.

The third is the problem of hunger. Food was a reoccurring theme of throughout many Victorian novels because of the hunger that many people faced in this time period. This theme is reflected in the vivid description of under nourishment at Lowood School in Charlotte Bronte's Jane Eyre (Chesire, 2011, para.1). Although the issue of food is not always being the main theme in a novel story, but Bronte still put the hunger issue in her novel 
since it was also the reflection of her own experience.

The fourth is the issue of physical and mental health. The Victorians believed "an interdependent mind-body connection gained strength, and many people saw physical and mental health as being interrelated rather than separate entities" (Mayer, 2004, para.1). These attitudes of the time are reflected in Bertha's (Rochester's wife) character through her mental illness and the physical threat she puts on Rochester. Jane and Bertha are total opposite. Jane has a strong body as well as her mind. She is able to endure the unhealthy states at Lowood where many students die and capable to survive despite the cold weather and hunger when she runs away from Thornfield and lives outside. Her mental strength has been visible through her courage as a little kid who survives with her evil aunt, intimidating cousin, and sanctimonious head master. She keeps pursuing her dream and tries so hard to become successful woman in this era despite all the hardships that she faces. In opposition to Jane, Bertha is claimed by Rochester as being "gone mad". The Victorians might view this as the absence of mental strength. Bertha also gives bad impression to Rochester trough physical threat by setting his bed on fire while he was sleeping, lunging at him and Jane in the room, and actually succeeding in burning down the house at the end of the book (Chesire, 2004, para. 4).Even the physical and mental health problem that became issue in Victorian era had been put in Bronte's writings. It proves that what happened in the reality affects the production of literary works.

Based on author's background and several reflections of Victorian era that we read before, we found out that the characteristics of the period when Jane Eyre was published are the social classes between high social status and low social status, the gender issues between men and women where women were interpreted as gender who had lower position than men, poverty and hunger for those who were from low social status, forbidden love between noble man and poor women, and issues regarding physical and mental health. After that, we can conclude that Charlotte Bronte was affected by the realities that happened during the time when Jane Eyre was published. She put her experience and social condition of the era when and where she lives in Jane Eyre. That is why based on genetic structuralism point of view, the novel Jane Eyre was produced because of several reasons based on historical aspects. The first is because the novelist experienced by herself the time when society in the mid-nineteenth century (Victorian era) perceived that women had no rights to speak and do anything that she desires. The second is the novelist experienced the poverty and hunger that usually happened on Victorian era. The third is the novelist experienced forbidden and even unrequited love between a married noble man and a poor single lady. The last is the expectation or imaginary of the author regarding a happy ending love between a married noble man and a poor single girl who loved each other.

\subsection{Analysis on the Great Gatsby}

\section{a. Analysis on the Novelist' Background and the Novel "the Great Gatsby" \\ Francis Scott Key Fitzgerald was born in} St. Paul, Minnesota on September 24, 1896. He became popular as a chronicler of the jazz age. Fitzgerald possessed a good fortune and misfortune as well during his career as a writer. His parents consist of an alcoholic failure father 
and an intensely ambitious mother. When he grew up, he was consciously aware of his condition and family origin and he knew exactly that he was excluded from social elite. In 1913 he entered Princeton and became a close friend of Edmund Wilson and John Peale Bishop. He spent most of his time writing lyrics for Triangle Club theatrical productions and analyzing how to triumph over the school's intricate social rituals (Cowley, 1951). Fitzgerald seemed want to be accepted and respected in the social elite circle of Princeton University. Jay Gatsby as the protagonist in the Great Gatsby also comes from poor family and also struggles to be accepted in the society by trying really hard to be rich.

Fitzgerald then was not able to graduate from Princeton University and he was inspired to write his first novel entitled This Side of Paradise (1920) which provides a protagonist named Amory Blaine where this character resembles Fitzgerald a lot. Fitzgerald achieved his first success with his first novel and won over his wife, Zelda. Matthew (1999) states that Fitzgerald tried really hard to make Zelda became his wife. He worked hard to write a good novel and when his first novel were sold for 41.075 copies in the first year of publishment, Fitzgerald proposed to Zelda and promised that he would be able support her financially. Jay Gatsby also tries so hard to make Daisy to be his by working hard to be a rich man so that Daisy would be interested in him.

Unfortunately, Fitzgerald had a glamour lifestyle. He liked to drink, had parties, and spent his money in vain without thinking about the consequences. This caused him to struggle to make enough money to cover all of his expenses.In 1922, Fitzgerald's second novel entitled the Beautiful and the Damned was published but it was not as successful as his first novel. Fitzgerald moved to France, and it was there, he wrote his master piece entitled the Great Gatsby. Mizener (1958) states that although the book was well-received when it was published, it was not until the 1950s and ' $60 \mathrm{~s}$, long after Fitzgerald's death, that it achieved its stature as the definitive portrait of the "Roaring Twenties," as well as one of the greatest American novels ever written. Jay Gatsby is also portrayed by Fitzgerald as a new rich man who consumes an extravagant lifestyle like him.

F. Scott Fitzgerald died believing himself a failure. None of his works received anything more than modest commercial or critical success during his lifetime. However, Bruccoli (1973) states that since his death, "Fitzgerald has gained a reputation as one of the pre-eminent authors in the history of American literature due almost entirely to the enormous posthumous success of The Great Gatsby. Perhaps the quintessential American novel, as well as a definitive social history of the Jazz Age, The Great Gatsby went on to become required reading for virtually every American high school student, and has had a transportive effect on generation after generation of readers." (para. 1)

His experiences provided Fitzgerald with a theme that would resurface throughout his career, as he later wrote: "a poor boy in a rich town; a poor boy in a rich boy's school; a poor boy in a rich man's club at Princeton.... I have never been able to forgive the rich for being rich and it has colored my entire life and works" (Stern, 1971, 164). Sterns explains further that "the whole idea of Gatsby is the critique for the society of unfairness of a poor young man not being able to marry a girl with money. This theme comes up again and again because I lived 
it." As a result, Fitzgerald's works seem dominated by plots of young, ambitious men, and his most common themes are those of class and mobility. By giving Tom Buchanan characteristics that could be described as unsympathetic Fitzgerald criticizes the upper class which Tom represents. The deaths of Gatsby, Tom's mistress Myrtle and her husband Wilson could be seen as a way for Fitzgerald to criticize the cruel impacts which were caused by social class and status. Falth (2013) states that Fitzgerald's decision on letting Tom and Daisy, as representatives of high social status to live their lives without any consequences although they have committed such big crime by murdering Myrtle, made Gatsby became the suspect and also caused Gatsby to die in vain is Fitzgerald's way to criticize the American society on that era.

Based on Fitzgerald's bibliography, we found out that originally, Fitzgerald was not born from rich family but since he lives in such a society where people act like they are noble person in Minnesota, Fitzgerald built his mind set to act that way. After he got success by writing The Great Gatsby he consumed a glamour lifestyle like what he wrote in most of his novels. It seems like Fitzgerald wanted to criticize the society at that time but he also wished to live a life style like what he criticized. The fact that he became alcoholic after getting much money and being famous by his masterpiece The Great Gatsby proves that actually what he wrote in his literary work is part of his mindset that had been affected by the society at that time.

\section{b. Analysis on the Period when "The Great Gatsby" was published.}

Written and set during the post-World War I economic boom of the 1920s, F. Scott Fitzgerald's The Great Gatsby (1925) can be seen as a chronicle of the American dream at a point in this nation's history when capitalism's promise of economic opportunity for all seemed at its peak of fulfillment. "Get-rich-quick" schemes abounded, and many of them succeeded, for it was a time when stocks could be bought on a 10 percent margin, which means that a dollar's worth of stocks could be purchased, on credit, for ten cents. So even the "little man" could play the stock market and hope to make his fortune there" (Tyson, 2006, 69). People at that time believed that as long as they worked they can be rich and being acceptable in the society as people who are from high social status.

What people of the American society in nineteenth century thought about American dream was not truly based on the reality. People might be deceived by capitalist ideology which promotes that everyone could be rich as long as they work hard so being rich is everyone's right. But the problem is not that simple. Not everyone who is rich in being perceived as noble man. In nineteenth American society, there were terms "Old Money" and "New Money." Those who were called Old Money were those who were originally born from rich family and inherit their family's inheritance. And New Money are those who worked hard by doing a particular business to earn much money. Although New Money had much money and could be called rich but they were still not belong to noble men since only Old Money which had power in economic aspect since their wealth will not be bankrupt because it 
is already heritance. Thus, the American society at that time was very complex to define richness.

Based on Fitzgerald's background and the analysis on the period when The Great Gatsby was published, we found out two main characteristics of the period when The Great Gatsby was published. The first, American dream was a crucial believe that American society adopted at that time. The second, the society classified rich people in two groups, "old money" and "new money" where "old money" was accepted and more respected in the society than "new money" at that time.

\section{RQ 2:}

How different periods create different kinds of story?

In literature, periods are named for rulers, historical events, economic power, intellectual or political or religious movements, or artistic styles. (Milton, 2014) The period from 18301901 is called Victorian Era and the period from 1901-1960 is called Modern Period. Of course both of them are really different to each other. Most Victorian novels tell about the interaction of people in their community. Victorian novels are more focused on how the deeds of an individual's whether it is a small or big issue, could influence more people in the community (Darcy, 2007). The concerns of Victorian novels are fit for Jane Eyre. In the story, Jane's figure is kind of description how a poor woman could go out from the patriarchy and does what she desires to do. While modern period believes that "there is no such thing as absolute truth. Everything is relative" (Lorcher, 2014, para.1).The Great Gatsby as the critique of American dream also clarifies to us that although people tried to work hard to be rich and being
New Money, the society would not necessarily consider them as the same level with Old Money since society's perception about richness is complex.

Every period might produce different literary works since every period has its own characteristics like what we see on Victorian period and modern period. The characteristics of each period might be influenced by the society's believes, society's needs, society's habits, and society's expectation (Kurasige, 2012). Whether Charlotte Bronte or F. Scott Fitzgerald were affected by the historical structure where and when they lived. Bronte was inspired by her own experiences in the society in writing Jane Eyre and Fitzgerald was inspired by his critiques and also his expectations for American society where and when he lived. After all, the different kinds of story are created by different kinds of periods by adopting and reflecting the historical structure of the authors and the social condition at that time. The production of the different story might be produced from the authors' real life as the reflection of society and also could be in several forms such as critiques of expectations for the society.

\section{CONCLUSION}

Jane Eyre as the example of Victorian period novel in British literature and The Great Gatsby as the example of modern period in American literature that have been used in this study propose that different period might produce different kinds of story since different periods have their own characteristics based on the society that lived at those periods. Based on genetic structuralism perspective, we found out that since the authors are impacted by the condition of the society where and when they 
live, it is important to consider and to know the

historical structures of the authors' society.

\section{REFERENCES}

\section{Primary Sources}

Bronte, Charlotte. (2011). New ed Jane Eyre. London: Vintage.

Fitzgerald, F. Scott. (2000). $3^{\text {rd }}$ Ed. The Great Gatsby. New York: Penguin Classics.

\section{Secondary Sources}

Andersson, Angela. (2011). Identity and Independence in Jane Eyre. Sweden: Mid Sweden University Press.

Bassnett, Susan. (1993). Comparative literature: a critical introduction. Oxford: Blackwell Publishers Ltd.

Bloom, Harold. (1985). Modern Critical Views: F. Scott Fitzgerald. New York: Chelsea House Publishers.

Bruccoli, Clark. (1973). The Great Gatsby: A fascimile of the manuscript. Washington, D. C: NCR

Chesire. (2011). Literary anlysis of Jane Eyre. Retrieved from https://sites.google.com/a/cheshire.k12.ct. us/victorian-era/influential-authors/thebronte -sisters/biography/jane-eyreanalysis/literary-anlysis-of-jane-eyre.

Cody, David. (2004). Charlotte Brontë: A brief biography. Retrieved from http://www.victorianweb.org/authors/bron te/cbronte/brontbio.html.

Cody, David. (2012). Social class. Retrieved from

http://www.victorianweb.org/history/Clas s.html.

Cowley, Malcolm. (2006). The stories of F. Scott Fitzgerald. Retrieved from http://www.history.com/topics/f-scottfitzgerald.

Darcy. (2014). What are common characteristics of Victorian Literature? Published in 2007. Retrieved from http://www.goodreads.com/topic/show/65 56-what-are-common-characteristics-ofvictorian-literature.Web.
Eagleton, Terry. (1976). Marxism and Literary Criticism. London: Routledge.

Falth, Sebastian. (2013). Social class and status in Fitzgerald's the Great Gatsby. Sweden: Halmstad University Press.

Gaskell, Elizabeth. (2004) The Life of Charlotte Brontë. Retrieved from http://lang.nagoya-u.ac.jp/ matsuoka/EGCharlotte.html.

Goldman, Lucien. (1971). Reflections on History and Class Consciousness. Engtrans by P. France. In Mészáros, I. [Aspects of History and Class Consciousness, pp 6584]. London: Routledge \& Kegan Paul.

Goldman, Lucien. (1964). The Hidden God: a study of tragic vision in the Pensees of Pascal and the tragedies of Racine. Eng Trans by Philip Thody. London: Routledge.

Kurasige, Scott. (2012).Each Generation Must Discover Its Own History: Some Thoughts on The Richard Aoki Debate (Part 1). Retrieved from http://www.8asians.com/2012/08/27/each -generation-must-discover-its-ownhistory-some-thoughts-on-the-richardaoki-debate-part-1/.

Lorcher, Trent. (2014). Modernism in Literature: Quick Overview. Retrieved from http://www.brighthubeducation.com/highschool-english-lessons/29453modernism-in-literature/.

Lundén, Rolf, Srigley, Michael. (2009). Ideas and Identities; British and American Culture. Lund: Student litteratur.

Martin, Robert. (1966). Charlotte Brontë's novels: the accents of persuasion. New York: Norton.

Matthew, J. (1999). New essays on the Great Gatsby. Cambridge: Cambridge Univ Press.

Mayer, Sonja. (2014). Victorians and their attitudes towards health. Retrieved from http://www.victorianweb.org/authors/bron te/cbronte/jane9.html

Meyer, Jim. (1997). What is Literature? A Definition Based on Prototypes. Work 
Papers of the Summer Institute of Linguistics, University of North Dakota Session. North Dakota: University of North Dakota Press,41 (1), 42.

Milton. (2000). Periods of English Literature. Retrieved from http://home.comcast.net/ stephen.gottlieb /romantic/periods.html.

Mizener, Arthur. (1957). Afternoon of an Author.Princeton: Princeton University Library, 1957; London: Bodley Head, 1958. Retrieved from http://www.biography.com/people/f-scottfitzgerald-9296261\#earlylife\&awesm= oHgr6KMJ5a1wQQ.Web.

Nestor, Pauline. (1987). Charlotte Brontë. Totowa, New Jersey: Barnes \& Noble Books.

Nur'aini, Witri. (2009). Genetic Structuralism Analysis on Lucky Jim by Kingsley Amis. Jakarta: State Islamic University Syarif Hidayatullah Press.

Peters, Maureen. (1974). An Enigma of Brontës. New York: St. Martin's Press.

Schneider, Helmuth. (2007). Technology, in Scheidel, Walter; Morris, Ian; Saller, Richard. The Cambridge Economic History of the Greco-Roman World. New York: Cambridge University Press.

Stern, Milton R. (1971). The Golden Moment: The Novels of F. Scott Fitzgerald. Urbana: University of Illinois Press.

Sumo, Nova. (2014). Parallels between charlotte brontï ${ }_{i}^{1} / 2$ 's life and Jane Eyre. Retrieved from https://sumonova.com/parallelsbetween-charlotte-bronti\% C2\%BDs-lifeand-jane-eyre/.

Tyson, Louis. (2006). Critical Theory Today 2nd $E d$. New York: Routledge. 